\title{
First-Year Students with Specific Learning Disabilities: Transition and Adjustment to Academic Expectations
}

\author{
Wanda M. Hadley, Darla J. Twale, and James Evans
}

The American Council on Education (HEATH, 1989) indicated that opportunities for students with learning disabilities are expanding in postsecondary education. Nearly a third of all first-year students with some form of disability report that they have a learning disability (Brinckerhoff, 1993; HEATH, 1995; Scott, 1997). Carlton and Walkenshaw (1991) and Scott (1997) have reported that postsecondary educators are finding more students with learning disabilities in their classes. However, the college environment does not include the degree of shepherding expected in K-12 settings where students with learning disabilities have multidisciplinary teams available for planning and intervention regarding their learning disability, and more individual attention such as IEPs, special classes, tutors, and resource room instruction. With this kind of previous educational experience, students with learning disabilities may become accustomed to learning in a direct-teaching format rather than the traditional, teacher-centered college or university classroom structure (Brinckerhoff, 1996). Even though postsecondary institutions are required by law to provide accommodating services such as note takers, extra time to complete exams, and/or alternative test formats, they are not required to design special academic programs for students with learning disabilities. The purpose of this study was to identify how traditional-age, first-year students with specific learning disabilities make the transition and adjust to collegiate academic expectations.

\section{Theoretical Framework}

\section{Definition of Learning Disabilities}

The American Council on Education (HEATH, 1991) defined learning disabilities for college age students as

a disorder that affects the manner in which individuals with normal or above average intelligence take in, retain, and express information. It is commonly recognized as a significant deficit in one or more of the following areas: oral expression, listening comprehension, written expression, basic reading skills, reading comprehension, mathematical calculation, or problem solving. Individuals with learning disabilities also may have difficulty with sustained attention, time management, or social skills. (p. 1)

\footnotetext{
Dr. Wanda M. Hadley is a counselor and administrative faculty member and development writer, Dr. Darla J. Twale is a Professor of Higher Education Administration, and Dr. James Evans is an Associate Professor of Counselor Education and Human Services, all at the University of Dayton in Ohio.
} 
Success for all college students, however, requires new students to adjust, socially and intellectually to the college setting (Tinto, 1993). This adjustment typically requires a degree of physical separation and emotional detachment from significant others along with an acceptance of college level expectations, norms, rules, and regulations (Schlossburg, Lynch, \& Chickering, 1989). This expectation becomes more compelling with students with learning disabilities who may have difficulty dealing with testing, classroom instructions, materials, and response methods. In accordance with mandates to provide reasonable accommodations (Shaw \& Dukes, 2001), Brown, Clopton, and Tusler (1991) believed higher education administrators also have a responsibility to assist students with learning disabilities in the development of their independence. Students are expected to deal with increased levels of personal freedom (Brinckerhoff, 1996), the unique challenges presented by their disabilities (Conyers, Schaefer Enright, \& Strauser, 1998), and the performance of acceptable social skills (Mellard \& Hazel, 1992).

Involvement and integration into the campus culture bridges the marginalization and isolation that typically affect the transition from K-12 to higher education of students with learning disabilities (Astin, 1985; Tinto).

Individual growth and development during students' transition to postsecondary education progresses as a result of challenges they face and obstacles they must overcome. During their transitions from high school to college, students with learning disabilities need to develop new skills and change their behavior as they shift from one educational environment to another. Lynch and Gussel (1996) found that for postsecondary students with disability-related needs for accommodations, effective disclosure of their disability and self-advocacy strategies were valuable contributions to success. Durlak, Rose, and Bursuck (1994) argued that self-determination skills such as stating one's disability and identifying instructional accommodations with instructors are strategies related to a successful transition. Carroll and Johnson Brown (1996) proposed training in self-advocacy skills to enable students to become more autonomous adults and avert social isolation.

Chickering (1969) provides the major theoretical framework for this study through three of his vectors of college student development that discuss the movement of the entering student toward greater competence, self-advocacy, and autonomy.

Chickering defined developing competence as the student's ability to develop intellectual competence and acquire new information, to reach physical competence, and to expand interpersonal competence, and work cooperatively with others. To manage emotions, the learner focuses on self-control and expressing him or herself appropriately to circumstances. The third vector, developing autonomy or interdependence, entails the student's learning emotional independence or freedom from the need for constant reassurance, affection, and approval from parents, peers, and others. Chickering noted that in this vector, the student's experimentation with independence begins with disengagement from parents.

Students with learning disabilities are a growing population entering postsecondary education. Studying their transition through Chickering's framework can better help university personnel assist them in successfully integrating into the university environment. To this end, the following research questions were posed: (1) What types 
of academic experiences challenge students with dyslexia or reading problems on a selective, residential college campus as they transition from K-12 to higher education? (2) How do these traditional-age, first-year students with dyslexia or reading problems adjust to specific expectations to complete academic assignments such as homework, term papers, and other writing assignments? (3) What services do students with dyslexia or reading problems need to meet the academic requirements of the university environment?

\section{Methods}

\section{Population and Procedures}

This qualitative study was conducted on the campus of a midsized, selective, religious, coeducational, 4-year university. The university enrolls 10,300 students with first-year student enrollment reaching close to 2,100. There are approximately 300 students on campus who report having a learning disability and approximately 100 of those students were first-year students. Of these 100 students, 26 identified as having dyslexia or reading problems were selected because these students were faced with large general or comprehensive reading assignments that they must comprehend in order to be successful in their courses. Of the 26 students, the principal researcher interviewed and chose the first ten students who met the criteria for inclusion in the study: entered this university directly from high school and possessed documentation defining their learning disability as dyslexia or reading related issues. They represented each of the four academic units on campus: Arts and Sciences, Business, Education, and Engineering.

Nine study participants including seven females and two males began the study in the winter semester after they had completed one semester of academic study. The students agreed to participate in an initial focus group setting to discuss their academic experiences since they transitioned from high school. Although focus groups can be up to 12 or 14 persons, Krathwohl (1998) wrote that they are typically small, seven to ten persons and homogeneous in composition. According to Vaughn, Schumm, and Sinagub (1996), the optimum size for focus groups is 8 to 10 persons. They then shared any information in individual interviews that they would not feel comfortable sharing in a group setting. Finally, students participated in a second focus group session at the beginning of their sophomore year to offer final thoughts on their academic adjustment and reflect on additional assistance they needed.

\section{Data Collection}

Data were collected through three means: individual student artifacts, focus groups, and individual semi-structured interviews. Multiple data sources helped achieve triangulation (Newman \& Benz, 1998).

Student artifacts. The student artifacts collected for the study included class schedules, copies of written assignments for their classes (which included grade and faculty comments), class syllabi, and any tutoring reports. The authors hoped to gather 
information about difficulty responding to verbal directions, remembering information given in class, taking notes in class, or identifying main ideas in their papers (Putnam, 1984).

Focus groups. According to Vaughn, Schumm, and Sinagub (1996) the use of focus groups allows for an initial exploratory step in learning what to ask and how best to ask it. Questions for the initial focus group were based on Chickering's (1969) first vector, developing competence. Students discussed their transition to college, their perceived preparedness, and the impact of their disability on academic performance. The first focus group was conducted by the principal investigator after the students had their midterms and before finals, in an effort to interview them in a minimally stressful time.

The second focus group addressed the third vector, developing autonomy. Students reflected on challenges they have overcome, what services they needed, and significant changes they had undergone in their first year. Focus group interviews were one and a half to two hours long, audio-taped, and held in the third week of the fall semester of their sophomore year. Seven of the nine students returned to campus. Of the two that did not return, one said she would be transferring to another institution, and it is unclear why the second student departed from the university. All the students that completed the study were financially compensated.

Semi-structured interviews. Krathwohl (1998) argued that individuals with views different than the group may only feel comfortable sharing those in individual interviews. The principal investigator conducted a 1-hour audio-taped, semi-structured individual interview with all nine students to glean more specific information about particular incidents and situations not shared in the focus group. They responded to questions drawn from an understanding of Chickering's (1969) second vector, managing emotions. The protocol centered around how students dealt with their disability, sought assistance, coped with difficult, unclear assignments and unsatisfactory grades or paper comments, as well as how they met the challenges and temptations to use their disability as an excuse. The individual interviews were conducted over a 2-week time frame following the first focus group, prior to finals. It was important that the principal investigator conduct all interviews in an effort to establish rapport with the participants.

\section{Data Analysis}

An inductive analysis process was used for interpreting the data by going through the transcripts and using a coding scheme that attached meaning to words, phrases, and scenarios that continually emerged. Patton's (1987) discussion of the inductive analysis format enabled an examination of the patterns and themes that emerged out of the data. The authors looked for ways to establish linkages and relationships with data (Preissle Goetz \& LeCompte, 1984) and tied the themes back to Chickering's vectors in terms of how the participants met the challenges of transition and adjustment. 


\section{Results}

\section{Question 1}

One of the themes that emerged to address the first research question on developing competence indicated students felt the move from K-12 to higher education required greater personal independence. They must take charge of their lives and advocate for their own disabilities. A male Business student said, "You have to pretty much manage your own time because you don't have anyone else to do it...." This change was described as initially overwhelming by students. According to student responses, in high school they did virtually no advocating for self because their parents took on that role, and as one student added, "you have someone batting for you." Four of the nine students felt more ownership of their disabilities while in the college environment. As a first-year student, the male Business major realized that "now I am pretty much on my own and I am dealing with it accordingly."

The advent of greater independence in this theme was contrasted with the minimal level of academic support, however. The lack of availability of personal tutors in college as compared to their high school experience was a major adjustment for most of the students. They were adamant about the campus Writing Center and the student-tutors not providing the kind of personalized, long term help they were used to or needed but rather offered only a short term, transitional group format. High school tutors were adults, rather than upper-class students, with professional degrees in education or learning disabilities. Most of the subjects voiced concern and discomfort about working with fellow college students and in a setting that included other students.

Though related to the first theme of independence, in a second theme students talked about the challenges of staying current with their coursework and often feeling discouraged and vulnerable to falling behind in their classes. A female Business major shared that while in high school she depended on her tutor to clarify things for her rather than taking the time to look up answers to assignments, but since transitioning to college she said, "I get a lot more frustrated because I have to deal with everything by myself." Students shared that they found that it takes them longer to complete assignments for their college classes and that the coursework was more challenging. One of the female Business students attributed her "slow reading" and her inability to "quickly get concepts" as affecting how she does in her classes. Because the former tutoring services were not available, a female Arts and Sciences student said she "felt prepared to do the work on her own but more time was needed." Another Arts and Sciences peer added that she felt less prepared to complete assignments, that retaining information was difficult because more is involved and learning the material does not come easy. A female business student attributed her problems to being a slow reader who was unable to get the concepts quickly.

\section{Question 2}

One of the themes that surfaced for the second research question on managing 
emotions was the need to work harder to complete the assignments given to them because of the amount of work and the rigorous expectations of faculty. Most of the students in the study believed that the academic demands of college life forced them to work much harder than they had in high school. Their college professors expected them to produce more work and their expectation of quality was much more demanding than their high school teachers. Several of them referred specifically to the amount of writing assignments they had to complete in college versus high school, when they talked about some of the specific adjustments they had to make. The female Education major said, "I came from a very well established academic high school, but I never had to write so many papers." Three female students agreed that they constantly pushed themselves to work harder than their peers and one added, "It frustrates me... to see people that don't even study for tests do a lot better than me and I have studied."

A second theme related to the first involved developing strategies for keeping current in all classes. Because students felt their classes were so demanding and the quality of work so important, they voiced concern about developing ways of staying afloat. Two female students shared that they were taking medication that helped them to "stay focused" and "concentrate." Some students mustered the courage to meet with their professors to discuss their disability, if need be, but also to clarify assignments. The need for comfort and familiarity with their professors was a prerequisite, however, to their willingness to interact with them. A female Business student offered that, "Unless I am comfortable with the professor I don't always like to ask them for help."

The expectation and need for detailed feedback or comments on their writing assignments was deemed important to staying current and minimizing frustration. One of the female Arts and Sciences students compared comments received on her paper from her various professors and concluded some are more helpful than others but expressed the desire to receive feedback from all of them. For instance, her English professor tended to "elaborate with comments about what she needed to do and why it was needed," but in larger classes, she realized professors may not have the luxury of such detailed comments. Another student only looked at the grade but was unlikely to read the comments especially if the grade was low, anticipating the comments might be too painful to read. Even though the students valued study groups and being able to ask questions of other students, most of them believed that their professors were the key to understanding what was going on in their classes. According to most of the students, any detailed form of feedback from the professor allowed them to estimate where they stood in the class because they were unlikely to receive the ongoing evaluation they received previously.

Assimilating into the campus environment was a third theme emerging from the interviews dealing with managing emotions. Students often remained private about the fact that they had a learning disability because they did not want fellow students to feel they were receiving special attention. Fitting in with the majority population seemed important to their adjustment process but they did not feel that their peers should know. Most of the students said that in their earlier academic years, they saw themselves as different, compared themselves more to their peers, and were harder on themselves. One of the female Arts and Sciences students asserted that she did not always like identifying 
herself to her professors because she did not want them to label or "pity her" or somehow feel she was different. She added, "I am not ashamed at all that I have a learning disability. It is just that it can be frustrating for people who don't know that I have it."

The final theme centered on the frustration that often led students to use their disability behind which to hide. Even though most of the students did not see themselves as habitually hiding behind their disability, several admitted that there were times when they were so frustrated by work requirements that they had offered their disability as a reason for not doing something. Students reported feeling really anxious when they took exams and needed special accommodations to feel any level of confidence. Examples they gave included times that they were allowed to rewrite papers because they did not do well, times when they would not study as much as they should have, and times when they tried to negotiate turning in assignments late because they had other things due at the same time. One female Business student became so overwhelmed she asked professors to move her test dates. While one instructor was accommodating, another was not, heightening her frustration. Another female Business student admitted she used her learning disability as an excuse for not doing well in her classes but, she lamented, "I can only do that a couple of times because I started feeling horrible about it."

\section{Question 3}

The major theme that surfaced regarding the third question on developing autonomy was that students felt that first they needed professors to understand the issues regarding teaching students with learning disabilities, and second, they needed structured discrete resources to address their particular needs. All of them agreed that most of their professors did not seem to understand their concerns or how to work with them, an experience that added to their frustrations. Students said their professors taught the class as if they already had some basic knowledge of the class and moved the class through the material fairly rapidly. Cooperative learning resources, such as study groups might help them stay current in their classes and prepare for exams. Several of the students talked about the tendency to procrastinate, and how easy it is now that they do not have close supervision from parents, tutors, and teachers, and that such a resource would be helpful in keeping them on track. Two of the students talked about feeling panic-stricken when they had procrastinated and realized the work was still there, and sometimes other work had piled onto that which was originally due. Students believed that the structure of meeting with others on a regular basis to discuss what was going on in class, comparing notes, and preparing for exams would be very helpful. They seemed to think the structure would provide them some level of assurance that they would not fall behind and parallel, somewhat, the support they were accustomed to in high school.

An anonymous and non-intrusive way of getting notes for their classes was mentioned. Reluctant to ask a professor for a copy of his or her notes, ask another student in the class to take notes for them, or take a recorder to the class and record the lecture, students viewed their options as inconvenient, embarrassing, and time 
consuming. A female Business student placed her tape recorder on a professor's desk prior to class and retrieved it at the end of class to maintain her anonymity. Students also requested additional accommodations during testing sessions such as extra time, quiet places, and proctors who were knowledgeable in the course content.

\section{Disc ussion}

\section{Developing Competence}

Data on the experiences of academically challenge students with learning disabilities, as they transition from K-12 to higher education, indicate that students remain challenged by their sudden independence, free unstructured time, a higher expectation of academic performance, and loss of adult supervision. Reaching Chickering's (1969) vector of developing competence is demonstrated by the student's ability to achieve and be productive. Therefore, the student's awareness of and struggle to deal with his or her newly found responsibilities, that come with being more independent and advocating for self, pose a concerted need for added skills that students with disabilities must gain as they adjust to college life. Self-advocating moves students with learning disabilities from the K-12 patterns of dependent behavior to a more responsible role. The challenge of developing competence, however, requires that students learn to interpret and integrate their academic materials independently because they are held responsible for their own work and interact less frequently with the professor (Chickering, 1969).

Managing their time appropriately might have been an issue for this student group because they were still learning to, as Chickering (1969) suggested, identify, prioritize, and define problems in a clear and workable way. This can be especially daunting for students with learning disabilities because they are used to having professional tutors work with them and guide them in the process of writing. In their attempts to gain competence, students still have not broken from the more sheltered high school pattern as they struggle to sever what Komarovsky (1985) referred to as the umbilical cord symbolizing their continued reliance on adult prompting and monitoring.

\section{Managing Emotions}

Findings related to the second research question reveal the types of frustration and anxiety that emerge as a result of the transition from K-12 to higher education: coping with the academic expectations, staying afloat in their classes, needing detailed feedback from their professors, assimilating discretely into campus life, recognizing accommodations as key to their academic performance, and using their disability as an excuse, thus feeling guilty as a result. According to Chickering (1969), during their need to manage emotions students are confronted with the task of responding appropriately to situations and events that occur in their lives. However, transitioning to an environment that offers minimal direct teacher contact overwhelms students who receive quite a bit of individualized attention in high school. Roessler, Brown, and Rumrill (1998) noted that 
the development of self-advocacy skills is a high priority for these students and that developing a relationship with professors is a positive step with which students struggle. Nelson, Smith, Appleton, and Raver (1993) also agreed that social support and a campus climate that favors peer and professor interaction affect the academic performance of students with disabilities. Knowing and interacting with professors enhances students' intellectual commitment and encourages them to think about their own values and future. Therefore, students should be encouraged by their advisors to meet with their professors regularly and strive for greater self-advocacy (see Carroll \& Johnson Brown, 1996; Chickering \& Gamson, 1991; Durlak, Rose, \& Bursuck, 1994; Hill, 1996; Lynch \& Gussel, 1996).

Chickering and Reisser (1993) believed that within the vector of managing emotions, students wrestle with feelings of frustration and struggle with finding ways to shift away from those feelings. Students, however, might not have success in this vector until they take some risks by letting their peers know they have a disability and discover that others may not view them as different or favored. In fact, taking ownership of their disability as a departure from their days in high school may prove the contrary. Frustrations that led students to use their disability as a crutch show they may be unable to take risks and move beyond this vector, thereby, hindering their abilities to develop academic competence. Structured experiences through orientation programs, counseling centers, or the disabilities office that offers study skills, and time and stress management sessions, for instance, may be valuable experiences for students to make the choice to participate in rather than mandatory attendance.

\section{Developing Autonomy}

In terms of the services these students need to meet the academic requirements of the university environment, students appear to want the university to offer services in the same manner in which they received them in high school, such as faculty who understand the issues surrounding students with learning disabilities, cooperative learning resources built into the infrastructure of the class so that students are not working in isolation, and anonymous, non-intrusive, and easier ways to manage their class requirements. Kravets (1996) cautioned that institutions of higher education are expected to provide accommodations and auxiliary aids so that students have an opportunity to participate in college life. Accommodations and auxiliary aids, however, should not alter the nature of the program or course, nor be significantly difficult for the university to provide. This must be balanced by the student's willingness to move beyond the dependency instilled in high school to a platform of self-advocacy needed to succeed in an environment that values personal independence and autonomy (Brown, Clopton, \& Tusler, 1991).

Chickering (1969) wrote that while developing autonomy, students begin to understand that their independence is enhanced as they recognize their responsibility to others. Students in the study may have felt unsure of themselves regarding their academic competence because they still depend on their professors to assure them of their progress through the unrealistic expectation of thorough, on-going feedback which 
is not always practical in large lecture formats (see Leyser, Vogel, Bruttle, \& Wyland, 1998). Chickering pointed out that in reaching autonomy, reliance is transferred to peers and non-parental adults, thus supporting students' need for study groups and more cooperative learning resources. Experimenting with developing a comfort level with peer tutors could be a way for students to grow more autonomous. Residence hall informal pairings may be more meaningful than campus-wide tutoring programs, for instance (Chickering \& Reisser, 1993). Faculty may offer cooperative learning features for students who need additional support services, where practical, through their own curriculum. Students may need to develop their own informal study support groups or emotional support groups with the assistance of the disabilities office and faculty advisors. Patton and Polloway (1987) believed that as more students with learning disabilities choose higher education as a viable postsecondary option, faculty, staff, administrators, and students should be searching for ways to maximize their chances for success.

This study is limited because of the small population studied at a single institution, the focus on one learning disability, and the assessment of only three of Chickering's vectors. Future research projects could include a longitudinal study that follows this student population and studies their progress through additional vectors of student development: establishing identity, freeing interpersonal relationships, developing purpose, and establishing integrity. Because this study interviewed only students with dyslexia and other reading problems, it might be revealing to study students who encounter problems with mathematics calculation or mathematics reasoning. The exploratory nature of the data lends itself to a broader look at students with learning disabilities either on other campuses or through survey techniques. With the increased use of computer technology in the curriculum, students with learning disabilities may be challenged further academically and emotionally to succeed (Twale \& Schaller, 2003). Therefore, the more we know about learning disabilities the better educators, high school guidance counselors, university administrators, student personnel workers, and disabilities directors can assist students who have become accustomed to support systems provided in the K-12 system that are unlikely to be available on campus. All members of the college/university community can educate themselves with regard to learning disabilities so incoming and continuing students feel welcome and involved in the academic community.

\section{References}

Astin, A. (1985). Achieving educational excellence. San Francisco: Jossey-Bass.

Brinckerhoff, L. C. (1993). Establishing learning disability support services with minimal resources. In M. Farrell (Ed.), Support services for students with learning disabilities in higher education: A compendium of readings (pp.54-63). Columbus, $\mathrm{OH}$ : Association for Higher Education and Disability.

Brinckerhoff, L. C. (1996). Making the transition to higher education: Opportunities for student empowerment. Journal of Learning Disabilities, 29(2), 118-136. 
Brown, D., Clopton, B., \& Tusler, A.(1991). Access in education: Assisting student from dependence to independence. Journal of Postsecondary Education and Disability, 9, 264-268.

Carlton, P. M., \& Walkenshaw, D. (1991). Diagnosis of learning disabilities in postsecondary institutions. Journal of Postsecondary Education and Disability, 9(12), 197-206.

Carroll, A., \& Johnson Bown, C. (1996). Disability support services in higher education: An extension of the rehabilitation process. Journal of Applied Rehabilitation Counseling, 27, 54-59.

Chickering, A., (1969). Education and identity. San Francisco: Jossey-Bass.

Chickering, A., \& Gamson, Z. (1991). Applying the seven principles for good Practice in undergraduate education. In A. Chickering \& Z. Gamson (Eds.), New Directions for Teaching and Learning no. 47 (pp. 63-70). San Francisco: JosseyBass.

Chickering, A., \& Reisser, L. (1993). Education and identity (2nd ed.). San Francisco: Jossey-Bass.

Conyers, L. M., Schaefer Enright, M., \& Strauser, D. R. (1998). Applying self efficacy theory to counseling college students with disabilities. Journal of Applied Rehabilitation Counseling, 29, 25-30.

Decker, K., Spector, S., \& Shaw, S. A. (1992). Teaching study skills to students with mild handicaps: The role of the classroom teacher. The Clearing House, 65, 280-284.

Durlack, C., Rose.E., \& Bursuck, W. (1994). Preparing high school students with learning disabilities for the transition to postsecondary education: Teaching the skills of self-determination. Journal of Learning Disabilities, 27(1), 51-59.

HEATH. (1989). Strategies for advising disabled students for postsecondary education. Washington, D.C.: American Council on Education.

HEATH. (1991). College students with learning disabilities. Washington, DC: American Council on Education.

HEATH. (1995). Getting ready for college: Advising high school students with learning disabilities. Washington, DC: American Council on Education.

Hill, J. (1996). Speaking out: Perceptions of students with disabilities regarding adequacy of services and willingness of faculty to make accommodations. Journal of Postsecondary Education and Disability, 12(1), 22-43.

Komarovsky, M. (1985). Women in college. New York: Basic Books.

Krathwohl, D. R. (1998). Methods of educational and social science research: An integrated approach (2nd ed.). New York: Longman.

Kravets, M. (1997). Hidden disabilities: Another diverse population. The Journal of College Admission, 152-153, 24-31.

Leyser, Y., Vogel, S., Brulle, A., \& Wyland, S. (1998). Faculty attitudes and practices regarding students with disabilities: Two decades after implementation of Section 504. Journal of Postsecondary Education and Disability, 13(3), 5-19.

Lynch, R., \& Gussel, L. (1992). Disclosure and self-advocacy regarding disabilityrelated needs: Strategies to maximize integration in postsecondary education. Journal of Counseling and Development, 74, 352-357. 
Mellard, D., \& Hazel, J. (1992). Social competencies as a pathway to successful life transitions. Learning Disability Quarterly, 15, 251-271.

Nelson, J., Smith, D., Appleton, V., \& Raver, K. (1993). Achievement-related beliefs of college students with disabilities. Journal of Postsecondary Education and Disability, 10(1), 9-20.

Newman, I., \& Benz, C. (1998). Qualitative-quantitative research methodology: Exploring the interaction continuum. Carbondale, IL: Southern Illinois University Press.

Patton, J., \& Polloway, E. (1987). Analyzing college courses. Academic Therapy, 22(3), 273-280.

Patton, M. Q. (1987). How to use qualitative methods in evaluation. Newbury Park, CA: SAGE Publications.

Preissle Goetz, J., \& LeCompte, M. (1984). Ethnography and qualitative design in educational research. Orlando, FL: Academic Press.

Putnam, M. (1984). Postsecondary education for learning disabled students: A review of the literature. Journal of College Student Personnel, 25, 68-75

Roessler, R., Brown, P., \& Rumrill, P. (1998). Self-advocacy training: Preparing students with disabilities to classroom accommodations. Journal of Postsecondary Education and Disability, 13, 20-32.

Shaw, S., \& Dukes L., III. (2001). Program standards for disability services in higher education. Journal of Postsecondary Education and Disability, 14(2), 81-90.

Schlossburg, N., Lynch, A., \& Chickering, A. (1989). Improving higher education environments for adults: Responsive programs and services from entry to departure. San Francisco: Jossey-Bass.

Scott, S. (1997). Accommodating college students with learning disabilities: How much is enough? Innovative Higher Education, 22, 85-100.

Tinto, V. (1993). Leaving college: Rethinking the causes and cures of student attrition. (2nd ed.). Chicago: University of Chicago Press.

Twale, D., \& Schaller, M. (in press). Mandatory computer purchases and student preparedness: Implications for new student orientation. Journal of College Orientation and Transition, 10(2), 60-69.

Vaughn, S., Schumm J., \& Sinagub, J. (1996). Focus group interviews in education and psychology. Thousand Oaks, CA: SAGE Publications. 